\title{
Measuring brand loyalty of consumers towards chicken brands in the KwaZulu-Natal Province of South Africa
}

\author{
CA Bisschoff \\ M Schmulian \\ North-West University, Potchefstroom, South Africa
}

Keywords

Brand loyalty, branding, chicken brand, antecedents, marketing, consumer.

\begin{abstract}
Brand loyalty is regularly categorised as one of the most vital drivers for ensuring the long-term sustainability of any organisation. Advantages of having a brand loyal customer base include lower sensitivity to price increases, lower brand switching intentions, high level of customer word-of-mouth marketing exposure and increased consumer profitability. The main focus of this study is to measure the brand loyalty of the KwaZulu-Natal consumers towards their uncooked chicken brand of choice using a validated model and its measuring instrument. The model was developed to measure brand loyalty in the fastmoving consumer goods industry but also successfully applied in agriculture, financial services and other industries. The model measures twelve of the most important antecedents influencing brand loyalty, namely perceived value, brand relevance, brand trust, repeat purchase, switching cost, brand affect, brand commitment, involvement, brand performance, relationship proneness, customer satisfaction and culture. The empirical study was conducted amongst 112 consumers in the KwaZulu-Natal Province of South Africa. A convenience sample was used to collect data through a product-specific adapted questionnaire designed to test how strongly each of the twelve antecedents relates to KwaZulu-Natal's consumer loyalty towards its chicken brand. The sample showed the appropriate adequacy, had low sphericity and were proved to be reliable as measured by Cronbach Alpha coefficients. The empirical results confirm the importance of each brand loyalty antecedent in chicken brands. This study offers the most important brand loyalty antecedents as a managerial guideline to chicken brands for consideration to implement in their customer loyalty marketing strategies.
\end{abstract}

Corresponding author: Christo Bisschoff

Email addresses for the corresponding author: christo.bisschoff@nwu.ac.za

First submission received: $20^{\text {th }}$ May 2019

Revised submission received: $9^{\text {th }}$ August 2019

Accepted: 21 ${ }^{\text {st }}$ August 2019

\section{Introduction}

The South African Agricultural Sector

The South African National Development Plan 2030 has identified agriculture, mining and manufacturing as significant drivers of job creation and growth in South Africa's economy. Agriculture has the most possibilities compared to the other two sectors. Furthermore, agriculture and agroprocessing are anticipated to create at least one million jobs by 2030. The South African agricultural sector is also vital regarding their role in food security, rural development and poverty alleviation (Department of Agriculture, Forestry and Fisheries, 2017:8). Employment in the agricultural segment increased by 5\% to 849000 employees in the third to last quarter of 2017 (Department of Agriculture, Forestry and Fisheries, 2017:9).

South African agriculture is confronted by increasing costs of production attributed largely to the high prices of inputs (fertilisers, seed and pesticides), electricity, fuel, mechanisation and labour. There are also additional challenges like frequent drought spells and outbreaks of pests and diseases. In the Department of Agriculture, Forestry and Fisheries' Annual Report for 2016/2017, Minister Zokwana said that the government initiated and funded drought-relief programmes worth R263 million. This followed the 2016 season was classified as one of the worst droughts the country has experienced since 1904 (Department of Agriculture, Forestry and Fisheries, 2017:13). 
The regulatory agricultural environment has also changed dramatically since the onset of democracy in 1994. Government subsidies have been discontinued and commercial farmers are now more price sensitive. In addition to the rising farm expenditure, and specifically labour costs regulated by the minimum wage legislation, farming activities shifted towards mechanisation and the use of capital intensive buying behaviour of farmers (Grainger, 2018). On the political front, the announcement of President Cyril Ramaphosa in December 2017 at the ruling party's conference that Land Expropriation without Compensation was going to be phased in after the Election in 2019, are a major concern for farmers. This, in conjunction with continued pressure on land reform from Julius Malema, leader of the opposing Economic Freedom Front party, have increased uncertainty in farming (The South African, 2019). Furthermore, the uncertain safety situation on farms and high volume of farm attacks (108) and murders (57.4\%) (for the period March 2017 to March 2018) also have a negatively influence farm investments (Head, 2018). As a result, investment and capital expenditure in farming is limited because farmers are unsure of their fate in the future (Bisschoff \& Grainger, 2019:4).

The Department of Agriculture, Forestry and Fisheries (2018:10) also reported that the agricultural sector succeeded to contribute $2.4 \%$ to the Gross Domestic Product in 2017. The total worth of agricultural production for 2017 was valued at R277,6 billion; this is 8,4\% higher than the previous year. The total worth of animal products contributed R137 billion, contributing nearly 50\% to the overall agricultural value (Department of Agriculture, Forestry and Fisheries, 2018:12). The Department of Agriculture, Forestry and Fisheries is continuously aiming to implement strategies to expand the sector. Table 1 below shows some of the focus areas and accompanying forecasts of expansion in the agricultural sector.

Table 1: Expansion of the Agricultural Sector

\begin{tabular}{l|l|l}
\hline Focus Area & From 2012 & To \\
\hline Increase number of Agricultural Smallholders & 171,670 & $471,670(2019)$ \\
Increase value-added activities of sectors & R42.5 billion & R48.9 billion (2019) \\
Increase the average value of annual exports & R5.1 billion & R7.4 billion (2019) \\
$\begin{array}{l}\text { The decrease in the average value of annual imports } \\
\text { of diesel, fertiliser and machinery }\end{array}$ & R9.6 billion \\
Increase the number of jobs in the sector & 660,000 & 1 million (2030) \\
\hline
\end{tabular}

The ZAR traded at \$14,87 US

\section{Agriculture in the KwaZulu-Natal province}

Agriculture has always been a major contributor to KwaZulu-Natal's economy, especially as KwaZulu-Natal is reckoned to be South Africa's best watered province and boasting 6.5 million hectares of high-quality agricultural land. The area between Pietermaritzburg and the Drakensberg, known as the Midlands, is regarded as the heart of the province's agricultural area. The North Coast region is another area of importance where several national leading agricultural products are produced. Some $82 \%$ of the province's agricultural land is fit for extensive livestock production, while $18 \%$ of this region have arable land. Even though KwaZulu-Natal covers a small portion of South African borders, a substantial proportion of the nation's small-scale farmers are based here. The diversity of the province's agriculture is also of note and relates to the patterns of the province's topography. KwaZulu-Natal has specialist capabilities in several agricultural products as a result of its decent and reliable rainfall throughout the year and its fertile soils (KwaZulu-Natal Top Business, 2018). The main focus of KwaZulu-Natal's agricultural sector consists of the following:

- Horticulture: Sub-tropical fruits, especially bananas, pineapples, cashew nuts, potatoes and other vegetables.

- Crops: Sugar and maize

- Forestry: Black wattle, SA pine, eucalyptus, saligna and poplar.

- Animal husbandry: poultry, beef, sheep (mutton and wool) and pigs (KwaZulu-Natal Top Business, 2018).

\section{Problem statement}

The South African uncooked chicken market, consisting of chicken pieces and also whole birds, is affected by feed cost that have increased significantly. The cost of feeding a chicken has increased by $157 \%$ 
from 2001 to 2012, while the selling price of a chicken remains under pressure due to cheap imports. During the same period, chicken prices have risen by only 61\% (Davids et al., 2015:73). To survive and remain competitive, South African chicken producers are forced to continuously improve on efficiency and constantly generating new competitive strategies to attract new customers and maintain their current customer base (Esterhuizen, 2006:1). One such strategy is to effectively brand chicken products and target the different brands to specific market segments to acquiring a competitive advantage by creating a brand loyal customer base (Jandaghi et al., 2011:153). Kyriakidis and Rach (2010:7) among many other strategist's state that there are many advantages in creating brand loyal customers. One such advantage is that such customers are usually less sensitive to price escalations of and loyal customers are also prepared to pay a premium price to obtain their brand of choice. By creating a strong brand and loyal customers, brand management can become a strategic thrust toward profitability. However, to effectively manage a brand and its loyalty, management must measure the levels of brand management across several key brand loyalty indicators (Moolla and Bisschoff, 2012a:342). This is where the problem in the chicken industry lies. There is no tailor-made model to measure brand loyalty in the chicken industry.

This study then proposes to address the above problem by using a South African brand loyalty model developed for the fast-moving consumer goods industry, to measure the brand loyalty of uncooked chicken brands in KwaZulu-Natal.

\section{Objectives of the study}

1. The primary objective of this study will be to measure the brand loyalty of KwaZulu-Natal consumers towards their chicken brand.

2. The secondary objectives are to:

3. Confirm the statistical validity of the twelve brand loyalty antecedents;

4. Measure the brand loyalty of KwaZulu-Natal consumers; and to

5. Determine the reliability of the collected data.

\section{Research methodology \\ Research design}

This study employs both a literature and an empirical research study. The literature study consists of two definite sections, and as a prelude first aims to explain the role of poultry in the country and then in the province of KwaZulu-Natal. The literature then focuses on theory to support a holistic understanding of the twelve brand loyalty antecedents that are used to measure the brand loyalty of customers. The South African twelve-antecedent model to measure brand loyalty, developed by Moolla (2010), is discussed.

A quantitative research approach was followed to collect data. The research was done in a predetermined manner, using a questionnaire that was developed and distributed online via a snowball sampling technique to consumers. Data were automatically captured once the electronic questionnaire was submitted online.

\section{Questionnaire development}

The questionnaire, developed, validated and applied by Moolla (2010), uses twelve antecedents that influence brand loyalty. The rationale behind using this questionnaire is to test how strongly each of the twelve antecedents relates to KwaZulu-Natal consumers' brand loyalty when it comes to their chicken brand of choice. The questionnaire also collects demographic information (age, gender and ethnicity), household income, chicken brand of choice and the relevance of certain factors believed to influence brand loyalty of customers in addition to measuring the brand loyalty antecedents customer satisfaction, brand trust, involvement, commitment, brand affect, brand performance, culture, brand relevance, repeat purchase, perceived value, relationship proneness and switching costs (Moolla and Bisschoff, 2012b). Although the model was initially developed to measure brand loyalty in the fast-moving consumer goods (FMCG) sector, its validity was proven across a number of industries such as pharmaceutical products (Du Plooy, 2012), the banking industry (Scholtz, 2014) and farming supplies (Wiese, 2014) and especially in agricultural applications (Wiese \& Bisschoff, 2015). Furthermore, in support of the Moolla model, a study by Do Vale and Duarte (2013:31) included frozen foods in their classification of FMCG products. 
The questionnaire contains five demographic variables (adapted specifically for the poultry industry), and 50 measuring criteria that measure the 12 brand loyalty antecedents on a 7-point Likert scale ranging from Strongly Disagree (1) to Strongly Agree (7).

\section{Sampling procedure, data collection and analysis}

The population consists of consumers in KwaZulu-Natal Province. This population was specifically selected to measure the brand loyalty of a specific geographical area that can be targeted in marketing strategies. A convenience snowball sampling strategy was followed. The sampling strategy allowed the population to recommend other consumers to form part of the study. The distribution was done by using a direct approach. This entailed contacting the marketing departments of various KwaZulu-Natal based radio stations and KwaZulu-Natal's based forums via email, social media platforms like Facebook and Twitter, and instant messaging applications such as WhatsApp and Facebook Messenger. Given the specific constraints regarding the timeframe of the study, 112 completed and usable responses realised. The Kaiser-Meyer-Olkin measure of sampling adequacy and Bartlett's test of sphericity were used to determine the sample adequacy statistically. A Kaiser-Meyer-Olkin value of 0.77 indicates that the sample was adequate, while Bartlett's test showed minor sphericity of the data $(<0.05)$. This means that the data was suitable for analysis (Field, 2009:659). Statistical analysis comprised the IBM Statistical Package for Social Sciences (V25) (IBM SPSS, 2018).

\section{Assumptions}

Two assumptions were made about the physical form of a chicken and the brand of choice:

1. Any frozen chicken product in the form of raw meat, where a brand can be linked to that specific product.

2. Most probable link to a specific brand would be through the clearly demarcated trademark found on the product's packaging.

\section{South African Poultry Industry}

The poultry sector of South African has grown from what was, in essence, a backyard industry, to the established, effective and vastly productive commercial operations we see today. According to the South African Poultry Association (SAPA, 2018:5), the poultry sector remains the largest single contributor to the South African agricultural sector. In the year 2016, poultry production was responsible for $18 \%$ of the total agricultural gross value and more than $39 \%$ of animal product gross value. The sector offers direct employment for more than 47,000 people and employs another 59,000 people indirectly (SAPA, 2018:5).

The South African meat market is being dominated by chicken. This consuming rate has grown at such a tempo over the last decade, enforcing the poultry industry to improve and expand production. South African citizens consume more chicken than it is producing, forcing South Africans to rely on imported chickens to meet the demand. Figure 1 shows the relationship between South Africa's production, consumption and imports for 2016. Regardless of this development, the broiler industry was classified as an industry in distress by the South African Department of Trade and Industry (Davids et al., 2015:71).

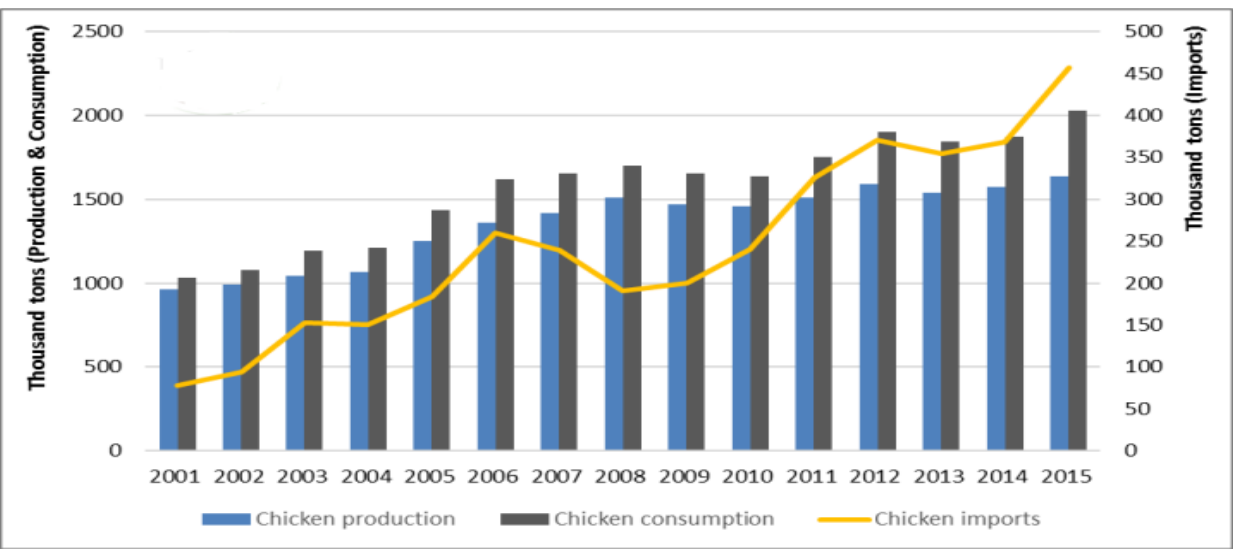

Figure 1: South African Chicken production, consumption and imports: 2001 - 2015 (BFAP, 2016:13)

www.jbrmr.com A Journal of the Centre for Business \& Economic Research (CBER) 
The South African poultry industry faced many challenges in the past decade, including:

Chicken producers have been under pressure for the last couple of years as feed cost has increased significantly. The broiler industry, a net importer of chicken, is cohesive into international prices and markets. From 2001 to 2012 the cost of feed has increased by 157\%, while the chicken price was kept to a low due to cheap imports. During the same period chicken prices have increased by only $61 \%$ meaning that the only mechanism to remain sustainable was by improving the efficiency and technology of production (Davids et al., 2015:73). Figure shows the average feed prices for broilers from 2001 to 2017. The price of soybean oilcake remains an essential aspect underlying the overall prices of feed and influencing the competitiveness of the broiler producers. About $18 \%$ of a broiler's weight is contributed by soybean oilcake. While South Africa has started increasing its volume to yield more soybean cake locally, they remain a net importer of soybean oilcake. Both Brazil and the United States of America are net exporters of soybean oilcake, inferring that the price of South African soybean oilcake trades at import parity levels, whereas Brazil and the USA can trade at prices of export parity levels (Davids et al., 2015).

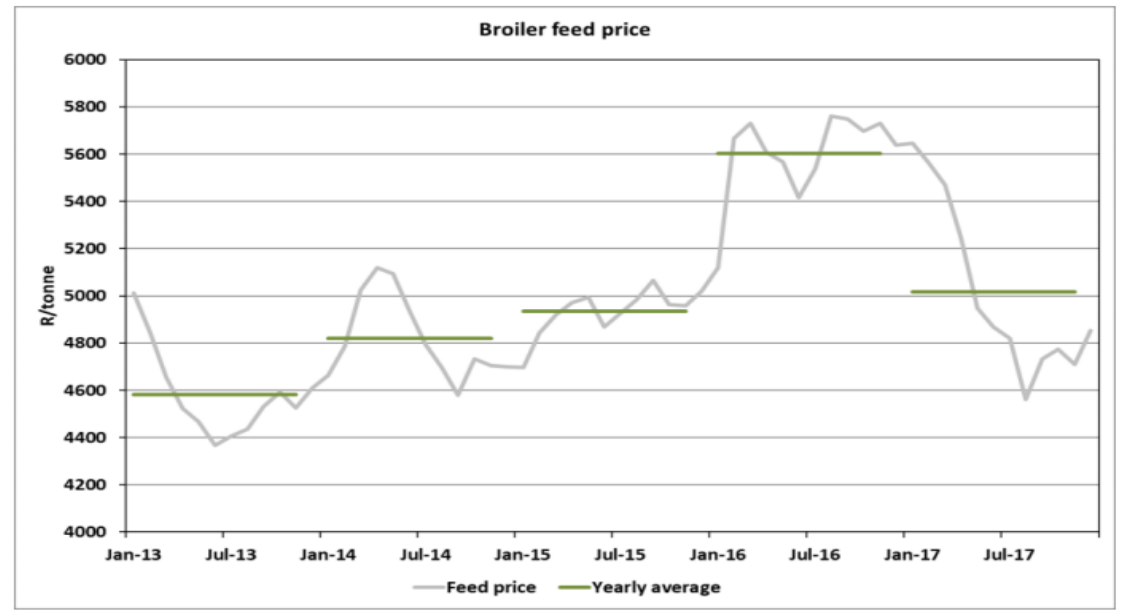

Figure 2: Average Broiler feed prices (SAPA, 2018:5)

The loss of thousands of jobs and revenue around R900m was given in exchange for South Africa to continue as the recipient of American's African Growth and Opportunity Act (AGOA). This agreement includes duty-free exporting of thousands of products to America, one of the biggest economies in the world. South Africa's exports account for 70\% of AGOA's (non-fuel) products justifying the decision by the government to remain a part of AGOA's R43.5bn foreign exchange earnings. Part of the agreement was the "dumping" of 65000 tons of bone-in brown meat pieces under normal importing obligation. At the time of the agreement, SAPA's CEO Kevin Lovell, said that it was potentially destructive to the poultry industry (Weavind, 2015:24).

According to SAPA, cheap EU poultry products were imported to South Africa at a price that local producers could not compete with. The government had established two task teams to urgently investigate the situation within the South African poultry industry to prohibit further job losses or farm closures because of dumping and uncompetitive practices by the EU, Brazil and the United States. In all practicality, cheaper chicken imports are supposed to be advantageous to the consumer (Department of Agriculture, Forestry and Fisheries, 2017:13-14).

In 2017, veterinary authorities in South Africa declared an outbreak of the highly pathogenic avian influenza (HPAI). This resulted in import bans from South Africa's neighbouring countries, 1300 lost jobs, and a loss of R954 million for the industry (Department of Agriculture, Forestry and Fisheries, 2018:14-15).

Dunn (2017:1), interestingly, mentions that imported chicken has reached a level where South Africa's harbours are having trouble in handling the import volumes. This is an aspect that could allow the local industry to utilise its surplus capacity to fill the logistical gap. He further believes that South Africa can take advantage of the global growth in the broiler industry by making use of the opportunity to enter the export market. The poultry industry's constant pleas for tariffs in support has so far fallen on 
deaf ears and the industry hopes to stimulate growth and job creation in the following years while still allowing fair trade with exporting nations (BFAP, 2016:104).

In a global context, competitiveness has become of prime importance for commercial producers with most countries protecting their trades by enforcing large tariffs. When dealing with such level of competition on an international scale, the significant risk of countries such as the EU, USA and Brazil, being able to dump their surplus or undesired meat in unguarded markets such as South Africa becomes a reality (BFAP, 2016:54). Chicken's role of supplying the South African market with a desirable and reasonably priced form of protein is contributing towards the strived level of food security (as stipulated in the Constitution of South Africa that South African citizens have a right to access adequate and reasonably priced food) (Davids et al., 2015:71). Laroche and Postolle (2011:1) argue that a country's basic foods needs cannot depend on imports and that long-term food security should rather be constructed by growing its local production while protecting this industry by implementing proper policies.

\section{Chicken brands}

It is important to understand what the concept "chicken brand" means in this study. The commercial chicken industry is no different from other chicken industries worldwide, and the product is generic. Here Scholtz (2014:1) states that one of the most important differentiators between brands reside only within the perception of the consumer whereby he or she differentiates a specific chicken product from the competitors. Chicken brands are differentiated through a specific trademark which is mostly found on the packaging of the different products. The concept "chicken brand" thus refers to the consumers' perceptions of that brand and its inherent qualities it possesses.

\section{The relevance of brand loyalty for chicken brands}

Given the competitiveness of the South African chicken market, it is crucial for businesses to not only concentrate on finding new customers but also to grow customers who are loyal to their brand. In addition, competitiveness also includes discovering ways of keeping their customers loyal (Bisschoff and Wiese, 2014:3). Holland and Baker (2001:42) mention that one of the many advantages of creating brand loyal customers includes the fact that such customers are generally less sensitive to escalations in the price of goods or services, due to the value these customers attach to the brand.

\section{Brand Loyalty}

Oliver (1999:34), at the turn of the century, defined brand loyalty as "a deeply held commitment to rebuy or re-patronise a preferred product/service consistently in the future, thereby causing repetitive same-brand or same brand-set purchasing, despite situational antecedents and marketing efforts that has the potential to cause switching behaviour." More recently, Huang et al. (2016:145) took a more simplified and practical approach in their definition and articulated the sense of behavioural loyalty as follows: "a customer's continuous purchase of a brand, as well as their repeated intention to purchase it in the future".

Brand loyalty involves a consumer's commitment to repurchase a brand through constant purchase (Moolla and Bisschoff, 2015:654). Brand loyalty also exists when customers have a notable and comparative attitude towards that brand (Hill, 2017: ii). These characteristics indicate that the repeat purchase behaviour is deeply connected to trust and quality of the product and service (Chaudhuri and Holbrook, 2001:85). This means striving towards a more long-term relationship-oriented approach with customers. Singh and Pattanayak (2014:40) confirm this approach shift by adding that reputable brands invest time and money to develop new product lines, conserving brand loyalty and preserving brand identity to increase its market share. Brand loyalty must be sustainable; this should be managed explicitly because satisfaction does not lead to brand loyalty (Schultz and Block. 2015:340). Therefore, it is important for marketing managers to gain enough knowledge about the concept of brand loyalty.

\section{Historical perspective of brand loyalty}

One of the first brand loyalty definitions has been developed by Jacoby and Kyner (1973:2) and describes brand loyalty as "the biased behavioural response expressed over time by some decision-making unit with respect to one or more alternative brands out of a set of such brands, and is a function of psychological (decision-making, evaluative) processes." Moolla (2010:60) also used this definition and added that brand loyalty could be described as a function of both attitudes and behaviour. 
Marketing researchers have in recent years shown great interest in the concept of brand loyalty, becoming one of the most frequently researched topics in the field of service marketing since 1990 (Moolla and Bisschoff, 2015:654). This interest is especially given the fact that customers with a high level of brand loyalty are least likely to be influenced by marketing campaigns of competitors (Lamb et al., 2010:385). Brand loyalty has a vital spot in business, especially inside the marketing facets of a business. Being a critical feature of a brand's value, the loyalty to it can assist a company in cutting costs on marketing expenses, having a non-sensitive customer base for price fluctuations, and it enhances an already loyal customer base to be even more loyal (Wiese, 2014:13).

According to Kuo and Hou (2017:257), a consumer is forced to classify similar brands into two kinds: the brands a consumer buys and the brands they do not buy. Brand loyalty is a complex behavioural concept. Ferrell and Hartline (2011:204) identified three brand loyalty components. They are:

\section{Brand Recognition}

Brand recognition is where a customer is merely aware of a brand, meaning the brand forms part of several other brands when the customer considers purchasing a specific product or service. This degree is considered to be the weakest form of brand loyalty.

\section{Brand Preference}

When a customer favours a specific brand over another, it is known as brand preference. The preference is, however, limited to cases where the brand is available at a point in time. This is a better form of brand loyalty, whereby a customer prefers a specific brand over an opposing brand. If the preferred brand is not available, the customer is most likely to purchase another brand.

\section{Brand Insistence}

This is the best degree of brand loyalty. The customer is so strongly insistent on a brand that the customer will pay a premium for that specific brand. This degree of brand loyalty will most likely cause the customer to go through a considerable amount of effort to acquire such a brand.

\section{Benefits of brand loyalty}

Kotler and Armstrong (2017:267) say that "a powerful brand creates equity for a company" and then define brand equity as "the differential effect that knowing the brand name has on customer response to the product and its marketing". They also mention that the characteristic of a consumer showing favour in a specific product above others is a characteristic of positive brand equity.

The increased interest in this topic shows that branding is not only a powerful marketing technique but a part of your product strategy. Branding can also be an asset to a company which must be established wisely and managed carefully (Kotler and Armstrong, 2017:267). IAS 18 of the International Accounting Standards (IAS), requires an entity to recognise a trademark as an intangible asset in the company's financial statements (Deloitte, 2017). This asset, in many cases, can be the most valuable asset on a company's balance sheet (Scholtz, 2014:11). Bisschoff and Wiese (2014:5) indicated that the benefits a company attain from having a brand loyal customer base are lodged in the value generated from the following state of affairs:

creation of a barrier to entry for competitors;

capability and capacity to counter the threats from competitors;

increased turnover; and

customers are less sensitive.

An essential benefit of satisfied and loyal customers is that these customers tend to become brand ambassadors who provide brand awareness and reassurance to new customers through word-of-mouth communication (Bianchi et al., 2014:94; Bıçakc1oğlu et al., 2018:865). Pride et al. (2009:375) state that brands have benefits for both sellers and customers. Table 2 provides a summarised synopsis of these benefits. 
Table 2: Brand benefits for sellers and customers (Moolla, 2010:31)

\begin{tabular}{|c|c|}
\hline Sellers & Customers \\
\hline $\begin{array}{l}\text { Identifies the company's products, makes repeat } \\
\text { purchases easier } \\
\text { Facilitates promotion efforts } \\
\text { Fosters brand loyalty - stabilises market share } \\
\text { Allows to charge premium prices and thus experience } \\
\text { better margins } \\
\text { Allows to extend the brand to new products and new } \\
\text { markets } \\
\text { Can communicate directly with the customer, reach } \\
\text { over the shoulder with the retailer } \\
\text { More leverage with middlemen } \\
\text { Is more resistant to price competition } \\
\text { Can have a long life }\end{array}$ & $\begin{array}{l}\text { Helps identify products } \\
\text { Helps evaluate the quality of a product } \\
\text { Helps to reduce the perceived risk in buying, assures } \\
\text { quality, reliability etc. } \\
\text { Is dependable (consistent in quality) } \\
\text { May offer a psychological reward (status symbol) } \\
\text { "Route map" through a range of alternatives } \\
\text { Saves consumer time } \\
\text { Is easier to process mentally }\end{array}$ \\
\hline
\end{tabular}

Organisations use vast amounts of resources to assure the upholding of their brand through service delivery across all of their branches. Garret (2006:35) states that companies thereby put a lot of worth in the imperceptible value of word-of-mouth and free marketing that a loyal client brings to an organisation (Garrett, 2006:35). An established brand can also result in increased turnover, not only for the branded product but also on other products associated with that brand. This method of co-branding is commonly utilised to improve brand equity and to assist in reaching a wider client- and demand base (Scholtz, 2014:12).

\section{Measuring brand loyalty}

Measurement is the way to characterise success in all industries (Kyriakidis and Rach, 2010:7). Kyriakidis and Rach (2010:7) also conveyed an astonishing fact that only one third of organisations measure the performance of their brand and that the valuable managerial information retrieved about a customer's loyalty towards a specific brand can be utilised to enable brands to strategically develop, implement and maintain an effective marketing strategy within the organisation.

There is agreement under researchers that loyalty, in a marketing sense, is a very complex concept (Javalgi and Moberg, 1997:169) and that most academics utilise the compound definition of brand loyalty as proposed by Jacoby (1971:25), there is, however, little consensus on the approach to be taken when measuring brand loyalty. As brand loyalty research has become more intense, the models of measurement have been purified and representative of the goods and segments it represents. However, one of the challenges often faced by researchers is the construction of a reliable and accurate measurement tool to statistically confirm brand equity research. It becomes even more challenging when a large number of variables and products are involved. However, it is most challenging when multiple dimensions of behaviour are added when measuring brand loyalty (Moolla and Bisschoff, 2015:654).

\section{Brand loyalty antecedents}

Moolla (2010) developed a brand loyalty conceptual framework to identify the antecedents that influence behaviour related to brand loyalty. The framework was developed through literature research of historical brand loyalty models (Moolla and Bisschoff, 2012a:75) to identify the most significant antecedents that play a role in the measuring brand loyalty in the fast-moving consumer goods (FMCG) industry. Initially Moolla (2010) identified 52 influences based on brand loyalty studies by much-admired academics (Jacoby and Chestnut, 1978, Traylor, 1981, Dick and Basu, 1994, Park, 1996, Chaudhuri and Holbrook, 2001, Giddens, 2010, Jensen and Hansen, 2006, Schijins, 2003, Musa, 2005, Rundle-Thiele, 2005, Punniyamoorthy and Raj, 2007, Kim et al., 2008, Maritz, 2007 and others). He reduced this list firstly to 26 antecedents, and then finally to 12 antecedents (see Figure 3). After that the model was statistically validated using structural equation modelling. The CFI of the model is 0.82 . This index signifies a fair fit as it exceeds 0.80 as index value (Bentler, 1990). 


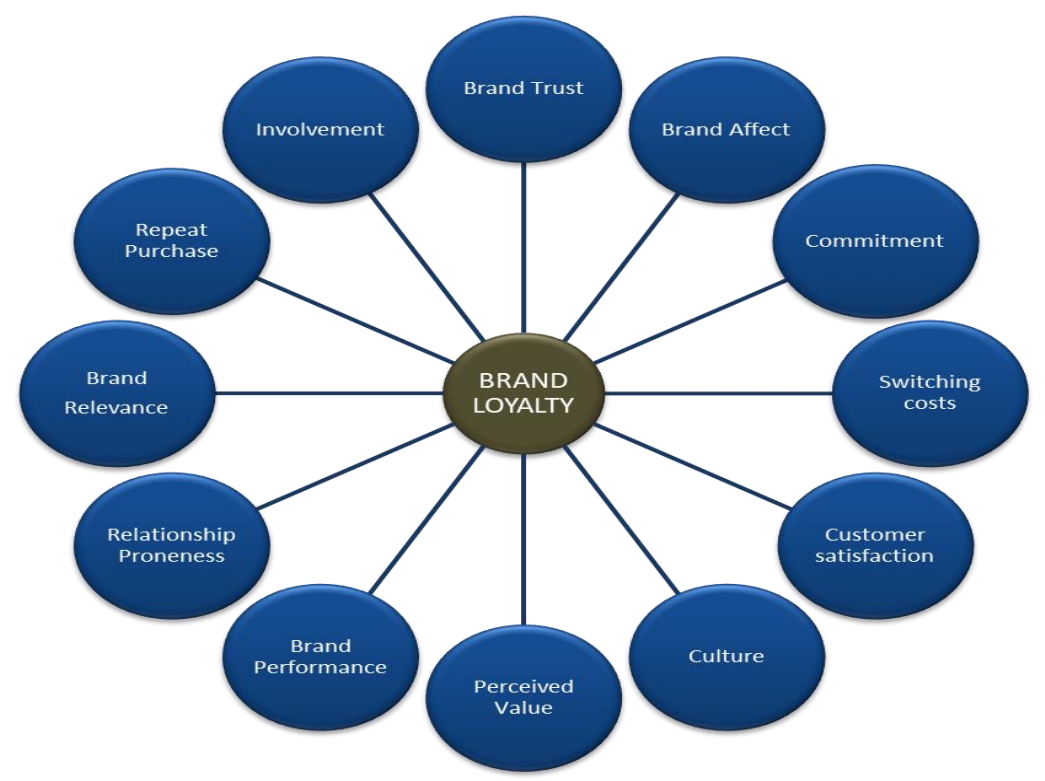

Figure 3: Moolla's brand loyalty model (Moolla, 2010:197)

Each of the twelve antecedents is shortly introduced below.

Brand Trust

Numerous definitions for trust exist, but most definitions emphasise the situational risk an individual take and the level of vulnerability the individual experiences due to the risk (Burke et al., 2007:606). According to Garbarino and Johnson (1999:70), trust can be the foundation of loyalty, due to the level of influence trust has to an individual's commitment. Moolla and Bisschoff (2012a:80) state that brand trust is grounded on perceptions that the brand is reliable and responsible for the interests and welfare of the individual. Trust in a brand is an emotional attraction to a product and forms the base of a long-term loyalty relationship. The perceived credibility and confidence of a customer towards a specific brand need to be measured in the formation of a customer's brand trust (Scholtz, 2014:21).

\section{Brand Affect}

Brand affect has either a positive or negative nature. There is a positive connection between the positive affect a consumer senses towards a brand and the willingness to buy that brand (Chaudhuri and Holbrook, 2001:81). How a brand affects customers, meaning how customers respond emotionally to their experience with a brand confirm that there is a robust relationship between brand affect and brand loyalty (Hill, 2017:12). Geçti and Zengin (2013:117) also found that brand trust has a substantial effect on brand affect. Brand affect, in essence, relates to the potential a brand has to provoke a positive emotional response within a consumer because he or she uses that brand (Chaudhuri and Holbrook, 2001:82).

Brand Commitment

Kim et al. (2008:99) view brand commitment as a behavioural intention with affective and cognitive motives. Commitment from a behavioural origin includes an emotional attachment to the brand, whereas commitment from a cognitive origin consists of motives like perceived risk or changes in the performance between opposing brands (Amine, 1998:309). Scholtz (2014:23) explains that the relationship a customer has with a brand plays an important role in the level of commitment. Evidence confirms that the lasting desire an individual has to maintain a relationship with a brand can be used as a measuring instrument to determine their commitment (Moolla and Bisschoff, 2012a:78). This level of commitment can be used as an indicator of the degree to which the brand is protected from their competition (Syed Alwi et al., 2017:401).

\section{Switching Cost}

Moolla and Bisschoff (2012a:80) defines switching costs as the costs incurred when a consumer stops buying one brand and start buying another brand of a similar product. This Switching may be caused by a change in buying behaviour of a customer, changing the environment, or when brand loyalty is low (Amine, 1998:308). High switching costs could act as a barrier to prevent switching to alternative brands (Moolla, 2010:128). When customers are brand loyal, they are less likely to switch to another brand 
even when price fluctuations or other market forces come into play within their preferred brand (Amine, 1998:314).

\section{Customer Satisfaction}

The level of satisfaction that a consumer relishes is influenced by previous consumer learning and experiences about a specific product or service (Vera and Trujillo, 2017:603). When the customer's expectations are not met, the customer becomes dissatisfied; this exposes the customer to alternative products as satisfying alternatives (Scholtz, 2014:20). Here Kotler and Armstrong (2012:37) describe customer satisfaction as "the extent to which a product's perceived performance matches a customer's expectations". Brand performance is considered the main driver of customer satisfaction (Awan and Rehman, 2014:29) and the importance of understanding the specific needs of its customers is key to provide satisfying products and services (Hill, 2017:25). It is therefore evident that an organisation needs to recognise the expectations of their clients including the degree to which their product or service meets the expectations of their clients (Lamb et al., 2015:6).

Culture

Lamb et al. (2015:107) mention that culture is "the set of values, norms and attitudes that shape human behaviour, as well as the artefacts, or products, of that behaviour as they are transmitted from one generation to another". Culture forms part of the social factor that influences the buying behaviour of an individual or a group of individuals. By not considering the cultures that form part of an organisation's client base, such organisation has virtually no chance of selling their products or services to such cultural segments of the market (Lamb et al., 2015:107). Also, Moolla and Bisschoff (2012a:79) stated that family, as a facet of culture, plays an important role by indirectly (and directly) inferring trust and protection through nostalgia and continuous use. The part that family preference plays towards brand loyalty is long-established by children remaining loyal to brands used by the family.

Perceived Value

Perceived value is described as the measurement of the price a consumer paid in acquiring a specific product in comparison with the efficacy or benefits a customer experience by using that specific product (Punniyamoorthy and Raj, 2007:225; Vera and Trujillo, 2017:603). Punniyamoorthy and Raj (2007:225) further add that a high level of brand loyalty can be achieved by a high perceived value perceived by clients. Researchers highly recommend that perceived value adds to a customer's brand loyalty. Perceived value is believed to be a combination of the following components:

Functional value;

Emotional value;

Social value; and

Price-worthiness factor (Voss et al., 2005:32).

Moolla (2010:131), however, pointed out that perceived value also consists of:

A functional value (use or performance of a product);

An emotional value (feelings a product generates);

A social value (product's capability to increase social self-concept); and

The price-worthiness influence (the concept of perceived value for money).

Brand Performance

Brand performance can be defined as the customer's evaluation of product or service performance after the usage thereof (Moolla, 2010:134, Unurlu and Uca 2017:673). Brand performance is usually connected when there is an increase in sales, market share and profitability of a company (Hill, 2017:16). By creating a better brand performance than competitors, organisations can increase their market share and charge a premium price (Chaudhuri and Holbrook, 2001:81).

Relationship Proneness

Relationship proneness can be defined as a personal trait of the customer and the customer's tendency to build a relationship with a brand (Moolla, 2010:129). According to Scholtz (2014:21), relationship proneness is "the degree to which a customer will engage in a relationship with a company selling a particular good". Relationship-prone individuals have higher levels of trust and commitment than individuals who are not relationship-prone (Kim et al., 2012:376). 


\section{Brand Relevance}

Brand relevance finds application during an individual's decision-making process, whereby the individual first identifies a product or service he/she would like to acquire while the subsequent step is to find a brand that is relevant to the identified product or service (Aaker, 2012:44). According to Moolla and Bisschoff (2012a:79) consumers are ever more looking for brands with relevance to their inner reference values and brands that actually represent something or someone that can increase value to their daily lives. For a brand to acquire relevance in the mind of a potential customer, such brand needs to be noticeable and be credible in respect of the specific category of product or service (Aaker, 2012:44).

Repeat Purchase

Punniyamoorthy and Raj (2007:226) believe that a habit of buying a specific brand will lead to the establishing of brand loyalty. Cleff et al. (2018:12) also state that brand loyalty has been measured by indicators such as repeat purchase frequency or relative volume of same brand purchasing. A habit of buying a specific brand is reached after a customer endures a sequence of recurrent repeat purchases of that specific brand. This customer then formulates a habit and unlikely to change to a different brand (Punniyamoorthy and Raj, 2007:226). Chaudhuri and Holbrook (2002:43) confirm that when brand loyal behaviour is established, it is difficult to change the behaviour. This brand loyalty behaviour will enhance repeated purchasing while also consolidating a brand loyal customer base (Chaudhuri and Holbrook, 2002:43).

\section{Involvement}

Product involvement comprises an ongoing commitment from the customer regarding his/her feelings, behavioural response and thoughts to a specific brand (Gordon et al., 1998:44). Moolla (2010:130) mentions the correlation between brand involvement and a customer's purpose and behaviour. He adds that brand involvement cannot be observed as it is a level of attention a customer has towards a specific brand. Several academic studies show that customer involvement can improve brand loyalty and the direct correlation between customer brand loyalty and brand involvement (Amine, 1998:312; Moolla, 2010:131; Vera and Trujillo, 2017:602).

\section{Results}

The results are presented about the secondary objectives.

Objective 1: Confirm the statistical validity of the twelve brand loyalty antecedents of the Moolla model (2010).

Empirical statistical confirmation requires that the measuring criteria of each of the antecedents prove belonginess to the specific antecedent. This is done by factor analysis. If all the criteria load onto the specific antecedent (factor), it shows validity in that the criteria indeed measures the specific antecedent. This means that the relevant criteria measure one construct only (Field, 2009:665). However, to do so, the data must also be suitable, and here sample adequacy, sphericity and also reliability are used to determine if the data is satisfactory. Numerous researchers such as Bisschoff and Moolla (2014), Fields and Bisschoff (2013a, 2013b), Shaikh (2017), and others have successfully validated their model antecedents likewise. The criteria and its factor loadings are also shown in Table 3.

Table 3: Business performance antecedents' suitability statistics

\begin{tabular}{llll}
\hline Antecedent & Sample adequacy & Sphericity & $\begin{array}{l}\text { Variance } \\
\text { explained }\end{array}$ \\
\hline Customer Satisfaction & 0.64 & 0.00 & $59.56 \%$ \\
Switching Costs & 0.69 & 0.00 & $48.97 \%$ \\
Brand Trust & 0.78 & 0.00 & $75.04 \%$ \\
Relationship Proneness & 0.61 & 0.00 & $38.03 \%$ \\
Involvement & 0.62 & 0.00 & $56.56 \%$ \\
Perceived Value & 0.58 & 0.00 & $56.89 \%$ \\
Commitment & 0.85 & 0.00 & $71.96 \%$ \\
Repeat Purchase & 0.78 & 0.00 & $69.72 \%$ \\
Brand Affect & 0.61 & 0.00 & $66.45 \%$ \\
Brand Relevance & 083 & 0.00 & $73.14 \%$ \\
Brand Performance & 0.59 & 0.00 & $51.24 \%$ \\
Culture & 0.94 & 0.00 & $60.59 \%$ \\
\hline
\end{tabular}


All the antecedents returned satisfactory results. All 12 antecedents have very good sample adequacies (the KMO value exceeds 0.70), possess high reliability Cronbach Alpha coefficients ( $a \geq 0.70)$ and also explain variances that exceed the minimum requirement of 50\% (Field, 2009:675) (the majority explains much higher variances; the antecedent "Legality" explains an exceptionally high variance of $91 \%)$. These satisfactory results indicate the antecedents are valid and indeed do measure what they are supposed to measure. Furthermore, the high factor loading (see Table 4) resulted in no simplification or reduction of measuring criteria. It is, therefore, concluded that the theoretical model is statistically valid and that all the criteria do actually measure the respective antecedents identified from the literature study. In practice, this means that the model is suitable to measure the brand loyalty in the poultry industry. Furthermore, it means that the antecedents and their respective measuring criteria are deemed fit to perform this measurement (Shaikh, 2017).

Table 4: Factor analysis on individual business performance antecedents

\begin{tabular}{|c|c|c|c|c|c|}
\hline $\begin{array}{l}\text { Customer } \\
\text { satisfaction }\end{array}$ & Factor loadings & Switching cost & Factor loadings & Brand trust & Factor loadings \\
\hline Q18 & 0.920 & Q13 & 0.797 & Q1 & 0.855 \\
\hline Q19 & 0.767 & Q14 & 0.901 & Q2 & 0.918 \\
\hline Q20 & 0.742 & Q15 & 0.570 & Q3 & 0.846 \\
\hline Q21 & 0.339 & Q16 & $0.300^{*}$ & Q4 & 0.647 \\
\hline Q22 & 0.699 & Q17 & 0.561 & & \\
\hline $\begin{array}{l}\text { Relationship } \\
\text { proneness }\end{array}$ & Factor loadings & Involvement & Factor loadings & Perceived value & Factor loadings \\
\hline Q34 & 0.462 & Q47 & 0.697 & Q27 & $<0.300^{*}$ \\
\hline Q35 & 0.813 & Q48 & 0.910 & Q28 & 0.865 \\
\hline Q36 & 0.645 & Q49 & 0.488 & Q29 & 0.573 \\
\hline Q37 & $<0.300^{*}$ & Q50 & 0.501 & Q30 & 0.605 \\
\hline Q38 & 0.365 & & & & \\
\hline Commitment & Factor loadings & Repeat purchase & Factor loadings & Brand relevance & Factor loadings \\
\hline Q8 & 0.812 & Q43 & 0.605 & Q39 & 0.707 \\
\hline Q9 & 0.671 & Q44 & 0.862 & Q40 & 0.792 \\
\hline Q10 & 0.876 & Q45 & 0.843 & Q41 & 0.871 \\
\hline Q11 & 0.911 & Q46 & 0.778 & Q42 & 0.835 \\
\hline Q12 & 0.754 & & & & \\
\hline Brand effect & Factor loadings & Brand performance & Factor loadings & Culture & Factor loading \\
\hline Q5 & 0.818 & Q31 & 0.676 & Q23 & 0.792 \\
\hline Q6 & 0.877 & Q32 & 0.377 & Q24 & 0.807 \\
\hline \multirow[t]{2}{*}{ Q7 } & 0.437 & Q33 & 0.515 & Q25 & 0.476 \\
\hline & & & & Q26 & 0.675 \\
\hline
\end{tabular}

* Omitted criteria; factor loading $\leq 0.30$

Objective 2: Measure the brand loyalty of KwaZulu-Natal consumers.

The results about Objective 2 firstly deal with the demographic profile, and then the measurement of how important each brand loyalty antecedent is. The demographic profile shows that about the age of the respondents, $33 \%$ of them were between the ages of 31 and 40 . Ages 18 to 30 years followed closely with $32 \%$, leaving ages 40 and above with $34 \%$ of the respondents. Gender wise the respondents are fairly equally presented with $53 \%$ female respondents. Quite surprisingly, the largest ethnic group were white respondents $(88 \%)$. Other ethnic groups are in the minority with a combined $12 \%$. In a census done by Statistics South Africa (2011:28), the black African population group represented a vast majority of $86.8 \%$ of KwaZulu-Natal's total population. Although the ethnic representation of the participants is not a representative of KwaZulu-Natal's population, the mix is satisfactory for buyers of the selected brands of chicken investigated in this study to launch a targeted marketing strategy. Regarding specific chicken brands of choice, Grain Field is the most preferred brand with $47 \%$, followed by Goldi at $21 \%$. Regarding the income, $26 \%$ of the respondents earn a monthly household income of R40,001 and more, followed by $22 \%$ who earn between R10,001 and R20,000 per month.

The results showing the importance of the measuring criteria and their respective standard deviations are displayed in Table 5. The seven-point Likert scale was converted into percentages for easy interpretation. The table also shows the theoretical source from which each criterion was developed. The 
mean percentage for each antecedent is shown adjacent to each antecedent. None of the standard deviations showed that significant differences between the views of the respondents exist.

Table 5: Importance of the antecedents and measuring criteria

\begin{tabular}{|c|c|c|c|c|}
\hline Antecedent & Measuring Criteria & Literature Basis & Mean & STD DEV \\
\hline \multirow{5}{*}{$\begin{array}{l}\text { Customer } \\
\text { Satisfaction } \\
(79.7 \%)\end{array}$} & $\begin{array}{l}\text { I am very satisfied with the FMCG } \\
\text { brands I purchase }\end{array}$ & Delgado et al. (2003:53) & $83.16 \%$ & 0.997 \\
\hline & $\begin{array}{l}\text { Distinctive product attributes in } \\
\text { FMCG keep me brand loyal }\end{array}$ & Saaty (1994:21). & $76.79 \%$ & 1.224 \\
\hline & $\begin{array}{l}\text { My loyalty towards a particular } \\
\text { FMCG brand increases when I am } \\
\text { satisfied with that brand }\end{array}$ & Anderson and Sullivan (1993:125) & $85.71 \%$ & 1.040 \\
\hline & $\begin{array}{l}\text { I do not repeat a purchase if I am } \\
\text { dissatisfied about a particular } \\
\text { FMCG brand }\end{array}$ & $\begin{array}{l}\text { Chen and Lue } \\
(2004: 26)\end{array}$ & $77.81 \%$ & 1.587 \\
\hline & $\begin{array}{l}\text { I attain pleasure from the FMCG } \\
\text { brands I am loyal towards }\end{array}$ & Leuthesser \& Kohli (1995:17) & $75.26 \%$ & 1.329 \\
\hline \multirow{5}{*}{$\begin{array}{l}\text { Switching } \\
(64.7 \%)\end{array}$} & $\begin{array}{l}\text { I do not switch FMCG brands } \\
\text { because of the high cost } \\
\text { implications }\end{array}$ & Klemperer (1987:388) & $65.31 \%$ & 1.604 \\
\hline & $\begin{array}{l}\text { I do not switch FMCG brands } \\
\text { because of the effort required to } \\
\text { reach a level of comfort }\end{array}$ & Beggs and Klemperer (1992:56) & $68.24 \%$ & 1.431 \\
\hline & $\begin{array}{l}\text { I avoid switching FMCG } \\
\text { brands due to the risks involved }\end{array}$ & Self-generated item & $66.96 \%$ & 1.566 \\
\hline & $\begin{array}{l}\text { I switch FMCG brands according } \\
\text { to the prevailing economic } \\
\text { conditions }\end{array}$ & Kim et al. (2012:379) & $56.38 \%$ & 1.547 \\
\hline & $\begin{array}{l}\text { I prefer not to switch FMCG } \\
\text { brands as I stand to lose out on the } \\
\text { benefits from loyalty programmes }\end{array}$ & Klemperer (1995:520) & $58.42 \%$ & 1.685 \\
\hline \multirow{4}{*}{$\begin{array}{l}\text { Brand } \\
(82.7 \%)\end{array}$} & $\begin{array}{l}\text { I trust the FMCG brands I am } \\
\text { loyal towards }\end{array}$ & Halim (2006:1) & $82.91 \%$ & 1.089 \\
\hline & $\begin{array}{l}\text { I have confidence in the FMCG } \\
\text { that I am loyal to }\end{array}$ & Morgan and Hunt (1994:23) & $83.29 \%$ & 1.090 \\
\hline & $\begin{array}{l}\text { The FMCG brands I purchase has } \\
\text { consistently high quality }\end{array}$ & Reast (2005:11) & $81.25 \%$ & 1.123 \\
\hline & $\begin{array}{l}\text { The reputation of an FMCG brand } \\
\text { is a key factor in me maintaining } \\
\text { brand loyalty }\end{array}$ & Raimondo (2000:33) & $83.55 \%$ & 1.149 \\
\hline \multirow{4}{*}{$\begin{array}{l}\text { Repeat } \\
\text { Purchase } \\
(63.6 \%)\end{array}$} & $\begin{array}{l}\text { I prefer to maintain a long-term } \\
\text { relationship with an FMCG brand }\end{array}$ & Dwyer (1987:18) & $72.83 \%$ & 1.439 \\
\hline & $\begin{array}{l}\text { I maintain a relationship with an } \\
\text { FMCG brand in keeping with my } \\
\text { personality }\end{array}$ & Bloemer (1999:106) & $61.35 \%$ & 1.669 \\
\hline & $\begin{array}{l}\text { I maintain a relationship with an } \\
\text { FMCG brand that focuses and } \\
\text { communicates with me }\end{array}$ & Davis (2002:10) & $63.90 \%$ & 1.781 \\
\hline & $\begin{array}{l}\text { I have a passionate and emotional } \\
\text { relationship with the FMCG } \\
\text { brands I am loyal to }\end{array}$ & Reast (2005:10) & $56.25 \%$ & 1.866 \\
\hline
\end{tabular}




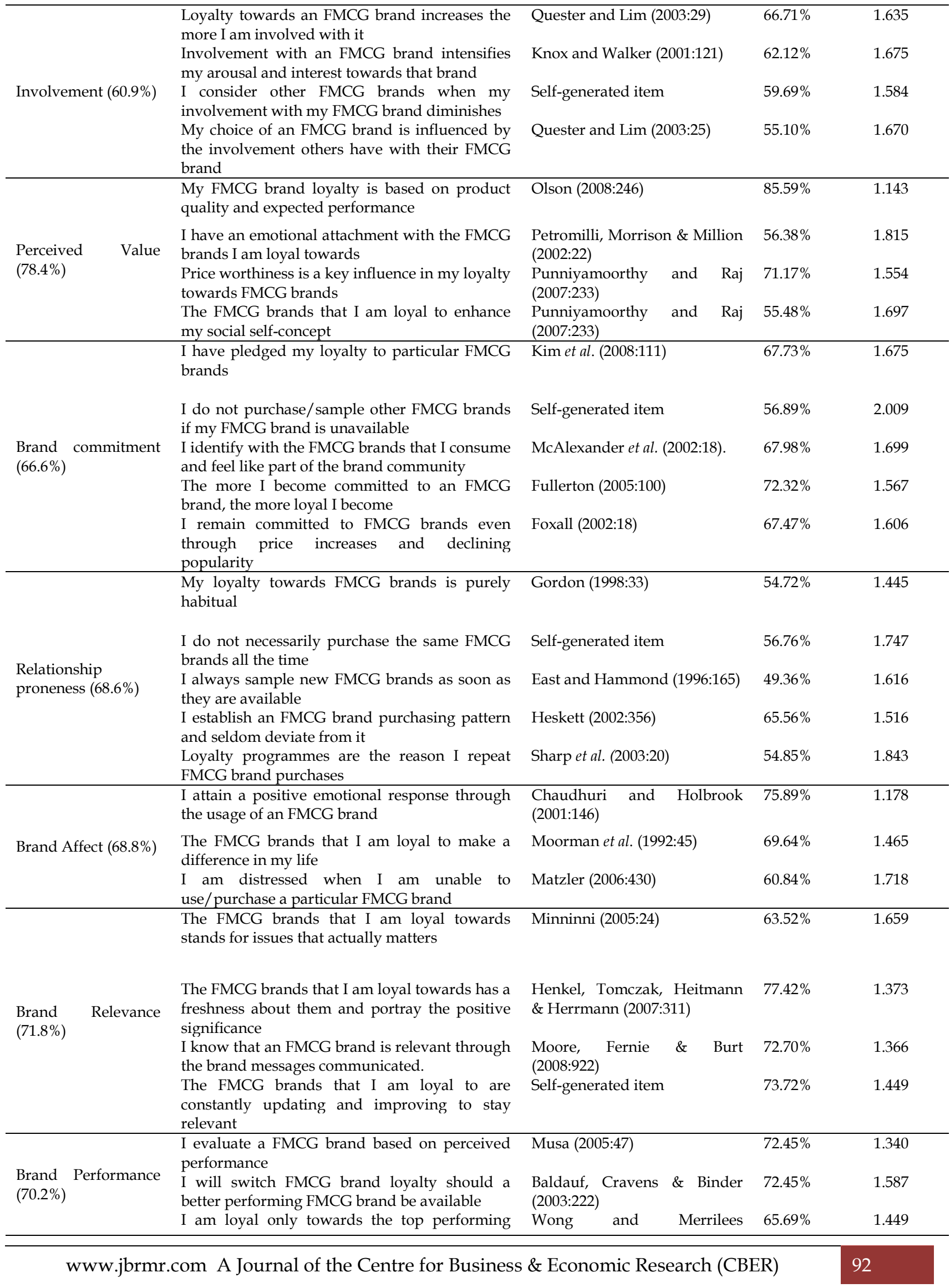




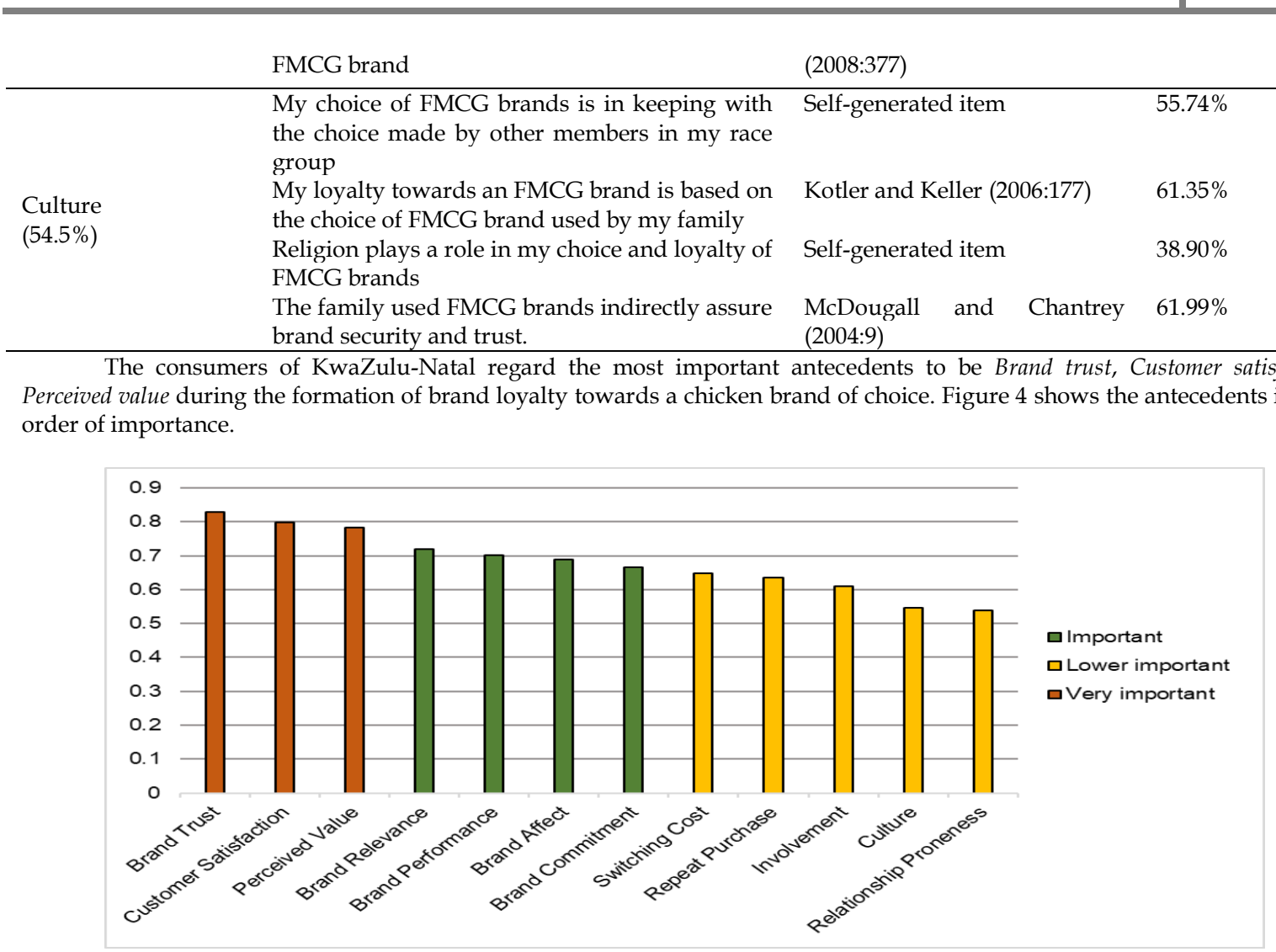

Figure 4: Brand loyalty antecedents mean percentages

Objective 3: Determine the reliability of the data.

The reliability and internal consistency of the antecedents are tested by calculating the Cronbach alpha coefficients. The results of each of the 12 antecedents are summarised in the table which also shows the number of measuring criteria used to calculate the alpha coefficient.

Table 6: Cronbach's Alpha reliability results

\begin{tabular}{llll}
\hline Antecedent & Criteria & Cronbach's Alpha & Number of items \\
\hline Brand Commitment & All (Q8 - Q12) & 0.90 & 5 \\
Brand Trust & All (Q1 - Q4) & 0.89 & 4 \\
Brand Relevance & All (Q39 - Q42) & 0.87 & 4 \\
Repeat Purchase & All (Q43 - Q46) & 0.85 & 4 \\
Customer Satisfaction & All (Q18 - Q22) & 0.78 & 5 \\
Culture & All (Q23 - Q26) & 0.77 & 4 \\
Switching Cost & Q13, Q14, Q15, Q17 & 0.77 & 4 \\
Involvement & All (Q47 - Q50) & 0.74 & 3 \\
Brand Affect & All (Q5 - Q7) & 0.71 & 2 \\
Perceived Value & Q28, Q30 & 0.71 & 4 \\
Relationship Proneness & Q34, Q35, Q36, Q38 & 0.61 & 3 \\
Brand Performance & All (Q31 - Q33) & 0.51 & \\
\hline
\end{tabular}

Table 6 shows that ten of the 12 antecedents' reliability have acceptable reliability because their alpha coefficients exceed 0.70 (Field, 2009:675). Two antecedents Brand Performance $(\mathrm{a}=0.51)$ and Relationship Proneness $(\mathrm{a}=0.61$ ) have coefficients between 0.50 and 0.70 ; they have a lower level of 
reliability (Field, 299:675; Cortina, 1993:101). The reliability of Relationship Proneness is still acceptable as the alpha coefficient exceeds 0.57 , but Brand performance is regarded as a marginally reliable antecedent to measure the brand loyalty of chicken (Cortina, 1993:101). This is unfortunate as Brand performance is regarded as an important antecedent (70.2\%) (see Figure 6).

\section{Conclusions and recommendations}

The following conclusions were reached based on the results of the study:

- The sample used in this study was adequate as the Kaiser-Meyer-Olkin measure of sampling adequacy yielded an average measure of 0.697 , ranging between 0.573 and 0.846 for all twelve brand loyalty antecedents.

- The data used in this study was reliable as per the Cronbach alpha coefficient. None of the twelve brand loyalty antecedents has an unacceptable Cronbach Alpha value of under 0.50, while two have lower reliability coefficients between 0.50 and 0.70. (Brand Performance at 0.51 and Relationship Proneness at 0.61 ). The other ten antecedents have satisfactory to excellent reliability coefficients larger than 0.70 .

- The statistical analysis confirmed that all twelve brand loyalty antecedents are valid to measure consumers' brand loyalty towards their chicken brand.

- It is concluded that the influences of Brand Trust, Customer Satisfaction, and Perceived Value are of the utmost importance when measuring a consumer's brand loyalty towards its chicken brand of choice. All three of these antecedents have mean values above $75 \%$, supporting the importance thereof.

- The other important influences are Brand Relevance (71.8\%), Brand Performance (70.2\%), Brand Affect (68.8\%), Brand Commitment (66.5\%), Switching Cost (64.7\%) Repeat Purchase (63.6\%), and Involvement $(60.9 \%)$.

- The two antecedents regarded as less important are Culture (54.5\%) and Relationship Proneness $(53.9 \%)$.

Based on the conclusions, the following recommendations are made:

The statistical techniques used in this study can successfully be applied within similar research projects.

The brand loyalty antecedent questionnaire initially developed by Moolla (2010) for purposes of the FMCG industry, can successfully be used to measure the brand loyalty antecedents of chicken brands.

Managers aiming to improve their chicken brand loyalty should address the more important antecedents first, moving down the order of importance to optimise their managerial interventions.

In support of Recommendation 4, given the importance and advantages of having a brand loyal customer base, it is important for chicken brands to focus on generating, implementing and maintaining strategies which can enhance a consumer's experience of Brand Trust, Brand Performance, and Perceived Value.

Management should use this research design as an example and extend this study to measure brand loyalty among other populations and culture groups. This should include the total geographic market segment.

Management should, after completion of Recommendation 6, devise diversified market strategies to specifically target the different population groups in their geographic market segment. This should include tailor-made marketing campaigns for the diverse target market.

\section{Limitations of the study}

The results obtained in this study are limited to uncooked chicken's brand preferences of KwaZuluNatal only. The remaining eight provinces of South Africa were not part of the study. In addition, the study also included chicken brands that are only distributed in KwaZulu-Natal. Therefore, the results cannot be extrapolated to the rest of South Africa. The results are also limited to the dominant cultural group who participated in this study. This poses another limitation because the respondents' profile is not representative of the profile of the South African population. This means that the results cannot be extrapolated to other cultural groups in KwaZulu-Natal. 


\section{Summary}

This article aimed to validate the FMCG brand loyalty model of Moolla so that it can be used in chicken brands. The article achieved this objective and then focussed on measuring brand loyalty of chicken brands in KwaZulu-Natal. The results showed that the model could successfully measure brand loyalty in chicken brands and identify the most important brand loyalty antecedents. These are Brand trust, Customer Satisfaction, and Perceived Value. Antecedents of lesser importance were Culture and Relationship Proneness. Finally, the study served as a pilot study for a national study. It aimed to ensure that the data collection methodology and measurements are possible using the chosen brand loyalty model and that the results are usable. Management can now engage in the more significant research project to measure their chicken brand's brand loyalty nationally and among the different population and cultural groups.

\section{References}

Aaker, D. A. (2012). Win the brand relevance battle and then build competitor barriers. California Management Review, 52(2), 43-57.

Amine, A. (1998). Consumers' true brand loyalty: the central role of commitment. Journal of Strategic Marketing, 6, 305319.

Awan, A. G., \& Rehman, A. (n.d.). Impact of customer satisfaction on brand loyalty - an empirical analysis of home appliances in Pakistan. British Journal of Marketing Studies, 2(8), 18-32.

BFAP. (2016). Evaluating the competitiveness of the South African broiler value chain. Bureau for Food and Agricultural Policy. Pretoria: BFA.

Bentler, P.M. (1990). Comparative fit indexes in structural models. Psychology Bulletin, 107(4):238-246.

Bianchi, C., Drennan, J., \& Proud, B. (2014). Antecedents of consumer brand loyalty in the Australian wine industry. Journal of Wine Research, 25, 91-104.

Bıçakcıŏlu, N., İpek, İ., \& Bayraktaroğlu, G. (2018). Antecedents and outcomes of brand love: the mediating role of brand loyalty. Journal of Marketing Communications, 24(8), 863-877.

Bisschoff, C.A., \& Grainger, B. 2019. Buying an agricultural tractor for commercial farming in South Africa. Paper presented at the 23 ${ }^{\text {rd }}$ International Farm Management Conference, Launceston, Tasmania, 22-27 March 2019. pp1-7.

Bisschoff, C.A., \& Moolla, A.I. (2014). A simplified model to measure brand loyalty. Paper presented at the $2^{\text {nd }}$ International Conference on Contemporary Marketing Issues, Athens, Greece, 18-20 June. pp. 1113-1120.

Bisschoff, C. A., \& Wiese, M. (2014). Brand loyalty of North West farmers towards their agricultural business. Paper presented at the International Business Conference, Victoria Falls, Zambia, 22-24-September. pp. 1-16.

Burke, C. S., Sims, D. E., Lazzara, E. H., \& Salas, E. (2007). Trust in leadership: A multi-level review and integration. The leadership quarterly, 62, 606.632.

Chaudhuri, A., \& Holbrook, M. B. (2001). The Chain of Effects from Brand Trust and Brand Effects to Brand Performance: The Role of Brand Loyalty. Journal of Marketing, 65, 81-93.

Chauduri, A., \& Holbrook, M. B. (2002). Product-class effects on brand commitment and brand outcomes: The role of brand trust and brand affect. Brand management, 10(1), 33-58.

Cleff, T., Walter, N., \& Xie, J. (2018). The Effect of Online Brand Experience on Brand Loyalty: A Web of Emotions. IUP Journal of Brand Management, 15(1), 7-24.

Cortina, J. M. (1993). What is coefficient alpha? An examination of theory and applications. Journal of applied psychology, 78(1).

Davids, P., Meyer, F. H., \& Louw, M. (2015). Evaluating the effect of proposed tariff protection for the South African broiler industry. Agrekon, 70-95.

Deloitte. (2017). IAS Plus - IAS 18 Intangible Assets. Retrieved October 16, 2018, from https://www.iasplus.com/en/standards/ias/ias38

Department of Agriculture, Forestry and Fisheries. (2017). Annual Report 2016/17. Department of Agriculture, Forestry and Fisheries, Pretoria.

Department of Agriculture, Forestry and Fisheries. (2018). Annual Report 2017/18. Department of Agriculture, Forestry and Fisheries, Pretoria.

Dick, A. S., \& Basu, K. (1994). Customer loyalty: toward an integrated conceptual model. Journal of the Academy of Marketing Science, 22(2), 99-113.

Do Vale, R. C., \& Duarte, J. (2013). Classification of FMCG Product Macro-Categories on the. Laboratório de Psicologia, 11(1), 29-36.

Du Plooy, H. (2012). Measuring brand loyalty in the Pharmaceutical industry of South Africa. Dissertation - MBA.

Dun, L. (2017). Can 2017 be a turning point for the broiler industry? AFMA MATRIX, 48. 
Esterhuizen, D. (2006). An evaluation of the competiveness of the South African agribusiness sector. Retrieved October 15, 2018, from http://upetd.up.ac.za/thesis/available/etd-12082006-144349/unrestricted/OOfront. pdf

Ferrel, O. C., \& Hartline, M. D. (2011). Marketing Strategy (5th ed.). South-Western Cengage Learning.

Fields, Z., \& Bisschoff, C.A. (2013a). A model to measure creativity in young adults. Journal of Social Sciences, 37(1), 5567

Fields, Z., \& Bisschoff, C.A. (2013b). A theoretical model to measure creativity at a university. Journal of Social Sciences, 34(1), 47-59

Garbarino, E., \& Johnson, M. S. (1999). The different roles of satisfaction, trust and commitment in customer relationships. Journal of Marketing, 63(2), 70-87.

Garrett, J. J. (2006). Customer loyalty and the elements of user experience. Design management review, 17(1), 35-39.

Geçti, F., \& Zengin, H. (2013). The relationship between brand trust, brand affect, attitudinal loyalty and behavioral loyalty: a field study towards sports shoe consumers in Turkey. International Journal of Marketing Studies, 5(2), 111-119.

Giddens, N. (2010). Brand loyalty. (A. D. Maker, Editor) Retrieved October 17, 2018, from http://www.extension.iastate.edu/agdm/wholefarm/pdf

Gordon, M. E., McKeage, K., \& Fox, M. A. (1998). Relationship marketing effectiveness: the role of involvement. Psychology and Marketing, 15(5), 39-45.

Grainger, B. 2018. Factors influencing farmers' buying behaviour regarding agricultural tractors in the North-West Province. (MBA Dissertation). Potchefstroom: North-West University.

Head, T. 2018. Farm murders: Six surprising facts we learned from crime stats 2017/2018. Retrieved Oct. 10, 2018 from https://www.thesouthafrican.com/farm-murders-crime-stats-2017-2018/

Hill, H. J. (2017). Measuring brand loyalty of farmers in the Free State Province towards their agricultural businesses. Dissertation - MBA.

Holland, J., \& Baker, S. M. (2001). Customer participation in creating site brand loyalty. Journal of Interactive Marketing, 15, 34-45.

Huang, S. M., Fang, S. R., Fang, S. C., \& Huang, C. C. (2016). The influences of brand benefits on brand loyalty: Intermediate mechanisms. Australian Journal of Management, 41(1), 141-160.

Jacoby , J., \& Chestnut, R. (1978). Brand loyalty: measurement and management. New York, NY: Whiley.

Jacoby, J. (1971). A model of multi-brand loyalty. Journal of Advertising Research, 11(1), 25-31.

Jacoby, J., \& Kyner, D. B. (1973). Brand loyalty versus repeat purchase behaviour. Journal of Marketing Research, 10(1), 1-9.

Jandaghi, G., Mehranjani, R. N., Seresht, M. N., \& Mokhles, A. (2011). Studying the effectof brand loyalty on customer service in Kerman Asia insurance company. Australian Journal of Business and Management Research, 1(6), 152158.

Javalgi, R. R., \& Moberg, C. R. (1997). Service loyalty: implications for service providers. Journal of Service Marketing, 11(3), 165-179.

Jensen, M., \& Hansen, T. (2006). An empirical examination of brand loyalty. Journal of Product and Brand Management, 15(7), 442-449.

Kim, H., Kang, J. M., \& Johnson, K. K. (2012). Effect of consumer relationship proneness on perceived loyalty program attributes and resistance to change. International Journal of Retail E Distribution Management, 40(5), 376-387.

Kim, J., Morris, J. D., \& Swait, J. (2008). Antecedents of true brand loyalty. Journal of Advertising, 37(2), 99-117.

Kotler, P., \& Armstrong, G. (2012). Principles of marketing (14th ed.). Maryland, NY: Pearson Education Limited.

Kuo, Y.-F., \& Hou, J.-F. (2017). Oppositional brand loyalty in online brand communities: perspectives on social identity theory and consumer-brand relationship. Journal of Electronic Commerce Research, 18, 254-268.

Kwazulu-Natal Top Business. (2018). KZN Agriculture. Retrieved April 19, 2018, from http://kzntopbusiness.co.za/site/agriculture

Kyriakidis, A., \& Rach, L. (2010). Hospitality 2010: a five year wake-up call. Deloitte and University of New York.

Lamb, C. W., Hair, J. F., McDaniel, C., Boshoff, C., Terblance, N., Elliott, R., \& Klopper, H. B. (2010). Marketing (4th ed.). Cape Town: Oxford.

Lamb, C. W., Hair, J., McDaniel, C., Boshoff, C., \& Tereblanch, N. (2015). Marketing (5th ed.). Cape Town: Oxford University.

Laroche, D. C., \& Postolle, A. (2011). Food sovereignty and agricultural trade policy commitments: What are the margins of manoeuvre for West African states? Paper presented at the European Association of Agricultural Economists (EAAE) Congress, EAAE, Zurich, Switzerland.

Maritz, J. (2007). Multidimensional loyalty model. Retrieved October 17, 2018, from http://www.maritz.com/AboutMaritz/Our-Businesses/Research/Multidimensional-Loyalty-Model.aspx

Moolla, A. I. (2010). A conceptual framework to measure brand loyalty. Thesis: PhD. . Potchefstroom: NWU. 
Moolla, A. I., \& Bisschoff, C. A. (2012a). A model to measure the brand loyalty for fast moving consumer goods. Journal of Social Science, 31(1), 75-85.

Moolla, A. I., \& Bisschoff, C. A. (2012b). Validating a model to measure the brand loyalty of fast moving consumer goods. Journal of Social Science, 31(2), 101-115.

Moolla, A. I., \& Bisschoff, C. A. (2015). A simplified model to measure brand loyalty of fast-moving consumer goods. Journal of Humanities, 4, 652-664.

Musa, R. (2005). Proposed conceptual model of satisfaction-attitudinal loyalty-behavioural loyalty chain: exploring the moderating effect of trust. ANZMAC 2005 Conference proceedings.

Oliver, R. L. (1999). Whence Consumer Loyalty? Journal of Marketing, 63, 33-44.

Park, S. H. (1996). Relationships between involvement and attitudinal loyalty constructs in adult fitness programs. Journal of Leisure Research, 28(4), 233-250.

Pride, W. M., Hughes, R. J., \& Kapoor, J. R. (2009). Business (10th ed.). Mason: Cengage Learning.

Punniyamoorthy, M., \& Raj, P. M. (2007). An empirical model for brand loyalty measurement. Journal of Targeting, Measurement and Analysis for Marketing, 15(4), 222-233.

Rundle-Thiele, S. R. (2005). Exploring loyal qualities: assessing survey-based loyalty measures. Journal of Service Marketing, 19(7), 492-500.

SAPA. (2018). Broiler industry stats summary for 2017. South African Poultry Assosiation. Pretoria: SAPA

Schijins, J. M. (2003). Loyalty and satisfaction in physical and remote service encounters. Bedrijfskunde, 74(1), 57-65.

Scholtz, L. (2014). Measuring brand loyalty in the hospitality industry in South Africa. Dissertation - MBA.

Schultz, D. E., \& Block, M. P. (2015). Beyond brand loyalty: Brand sustainability. Journal of Marketing Communications, 21(5), 340-355.

Shaikh, A.S.C. (2017). A conceptual model to measure the level of skills for managerial competence of business schooleducated managers in South Africa. Thesis - PhD. Potchefstroom: NWU.

Singh, P. K., \& Pattanayak, J. K. (2014, December). The Impact of Brand Loyalty on Consumers' Sportswear Brand Purchase. IUP Journal of Brand Management, 11(4), 40-52.

Statistics South Africa. (2011). National Cencus. Provincial profile: KwaZulu-Natal. Pretoria: Statistics South Africa.

Statistics South Africa. (2018). Quarterly employment statistics - June 2018. Pretoria: Statistics South Africa.

Syed Alwi, S. F., Muhammad Ali, S., \& Nguyen , B. (2017). The importance of ethics in branding: mediating effects of ethical branding on company reputation and brand loyalty. Business Ethics Quarterly, 27(3), 393-422.

The South African. 2019. Julius Malema explains how land expropriation will work under EFF. https://www.thesouthafrican.com/videos/julius-malema-land-expropriation-eff-policy/

Traylor, M. B. (1981). Product-involvement and brand commitment. Journal of Advertising Research, 21(1), 51-56.

Unurlu, C., \& Uca, S. (2017). The effect of culture on brand loyalty through brand performance and brand personality. International Journal of Tourism Research, 19(6), 672-681.

Vera, J., \& Trujillo, A. (2017). Searching most influential variables to brand loyalty measurements: An exploratory study. Contaduría y Administración, 62(2), 600-624.

Weavind, T. (2015). AGOA renewal: Local poultry industry loses out. Finweek, 24-26.

Welman, C., Kruger, F., \& Mitchell, B. (2005). Research Methodology (3rd ed.). Cape Town: Oxford University. Wiese, C. M. (2014). Measuring brand loyalty in Agribusinesses. Dissertation - MBA. Potchefstroom: NWU. 